\title{
Jazzowość filmu - filmowość jazzu. O muzyce Krzysztofa Komedy w filmach krótkometrażowych Romana Polańskiego
}

Images

vol. X/no. 19

Poznań 2012

ISSN 1731-450X

Kiedy w roku 1957 student wydziału reżyserii łódzkiej Szkoły Filmowej, niejaki Roman Polański, zapragnął - dodajmy: poza szkolnym programem - nakręcić film krótkometrażowy, wykorzystując w nim muzykę słynnego już wówczas kompozytora i pianisty jazzowego Krzysztofa Komedy, nikt nie przypuszczał, że będzie to początek nowego rozdziału, zarówno w historii polskiego jazzu, jak i filmu.

Przyglądając się z perspektywy ponad pięćdziesięciu lat wczesnej twórczości duetu Polański-Komeda, niełatwo udzielić jednoznacznej odpowiedzi na pytanie, który z artystów w większym stopniu wpłynął na dalszy rozwój drugiego. Jedno jest pewne: po ich pierwszej wspólnej etiudzie Dwaj ludzie z szafa w życiu Komedy i Polańskiego nastąpiły wielkie zmiany.

Pochylając się nad konkretnymi etiudami Romana Polańskiego, można dostrzec swoistą symetrię. Przejawia się ona na wielu polach. Jest obecna na płaszczyźnie filmowo-muzycznego porozumienia między reżyserem a kompozytorem oraz w samej strukturze filmu, nawet gdy rozpatruje się dźwięk i obraz niezależnie od siebie. Zabiegi, jakie stosuje Polański-reżyser, charakteryzują się, oprócz stricte filmowego, również myśleniem muzycznym (a nawet - wyrażając się bardziej precyzyjnie - jazzowym). I na odwrót - muzyka napisana przez Komedę-kompozytora, nie tracąc nic ze swych czysto muzycznych właściwości, zawiera w sobie wiele elementów szeroko pojętej filmowości.

Uzupełnianie się dwóch na pozór odmiennych tendencji przejawia się już w samej muzyce Krzysztofa Komedy. Wybitny trębacz Tomasz Stańko w swojej wypowiedzi, której udzielił w poświęconym autorowi muzyki do Noża w wodzie dokumencie Krzysztofa Riege, stwierdza, że dla Komedy kompozytorska twórczość filmowa była równie ważna jak praca nad jazzem. Według Stańki bardzo dużo zawdzięczał filmowi, jeśli chodzi o podejście do muzyki jazzowej, jak również jazzowi, jeśli chodzi o muzykę filmową.

Marek Hendrykowski rozwija tę myśl w sposób następujący:

Otóż ten wybitny kompozytor bywa najczęściej kojarzony z jazzem i muzyką filmową. $Z$ tą drugą poniekąd paradoksalnie, bo przecież znany jest dzisiaj ogółowi miłośników muzyki filmowej ledwie fragmentarycznie. W grę wchodzi w sumie dość wąska zbiorowa pamięć zaledwie kilku, w najlepszym razie kilkunastu tytułów, z którymi łączone jest jego nazwisko. To w końcu nie tak wiele. A już na pewno zbyt mało, żeby wyrobić 
sobie ugruntowaną opinię o klasie artystycznej tego wszystkiego, czego w ciągu zaledwie jednej fantastycznie twórczej dekady - dokonał ten genialny artysta[1].

Zdecydowana większość muzycznej spuścizny Krzysztofa Komedy to kompozycje jazzowe, z których spora część to muzyka pisana dla filmu. Zaznaczające się $\mathrm{w}$ twórczości kompozytora proporcje między jazzem a muzyką, która nim nie jest, bardzo dobrze przedstawiają właśnie etiudy Romana Polańskiego. Trzy z nich, a więc Dwaj ludzie $z$ szafa, Gruby i chudy oraz Ssaki, to filmy, w których, jeśli nie cała muzyka, to przynajmniej zdecydowana jej większość, okazuje się najczystszym jazzem[2]. Natomiast film dyplomowy reżysera, Gdy spadaja anioły, to mieszanina muzyki militarnej, kościelnej oraz ludowej. Alicja Helman tak komentuje owe pozajazzowe eksploracje kompozytora:

Komeda nigdy nie uważał jazzu za muzykę uniwersalną, zdolną obsłużyć wszystkie możliwe gatunki filmowe. Może dlatego najlepsze rezultaty uzyskał współpracując z twórcami młodymi, takimi jak Polański czy Komorowski [...]. Komeda jest przede wszystkim jazzmanem, ale przygoda filmowa wciąga go coraz bardziej. Istnieje wprawdzie wiele odmian jazzu i wiele możliwości wiązania go $\mathrm{z}$ filmem, ale X muza nie znosi najmniejszych ograniczeń i wymaga od swych adeptów wielkiej elastyczności. Wychodząc na spotkanie sztuki filmowej, Komeda zaczyna pisać muzykę, która właściwie nie jest już jazzem...[3].

To właśnie praca nad muzyką pisaną specjalnie do filmu ujawniła niespodziewanie potencjał kompozytora. Jazz pozostał naturalnie najważniejszym gatunkiem muzycznym, niejako punktem wyjścia do dalszych poszukiwań. Niemniej jedno z kolejnych spotkań z Romanem Polańskim, tym razem przy okazji filmu Gdy spadaja anioły, okazało się równie ważnym jak Dwaj ludzie z szafa punktem w muzyczno-filmowym rozwoju Krzysztofa Komedy - oczywiście nie w kontekście jazzu.

Ale, co szczególnie rzadkie i brzemienne w skutki, także Polański, zafascynowany muzyką jazzową, zaczyna wraz ze swym pierwszym w karierze umuzycznionym filmem przenosić zasady, jakimi rządzi się jazz, na terytorium X muzy. Następuje więc swoiste i szczęśliwe sprzężenie twórczych dążeń dwóch współpracujących ze sobą artystów.

Dwaj ludzie z szafa - mała improwizacja
Trudno uwierzyć, że muzyczny motyw przewodni z Dwóch ludzi z szafą oraz pomysł na sam film to dwie niezależne idee dwóch na pozór niezwykle różniących się od siebie twórców. Marek Hendrykowski w swojej książce o Komedzie przybliża okoliczności powstania słynnej kołysanki:
[1] M. Hendrykowski, Komeda, Poznań 2010, s. 150-151.

[2] Z tego powodu trzy wyżej wymienione filmy będą przedmiotem dalszych rozważań.
[3] A. Helman, Na ścieżce dźwiękowej. O muzyce w filmie, Kraków 1968, s. 138-139. 
Wspaniały temat przewodni, który znamy z filmu Dwaj ludzie z szafą, był jedną z jego pierwszych kompozycji kiedykolwiek dotąd napisanych. Według relacji Zofii Komedy i Jana Ptaszyna Wróblewskiego, temat powstał kilka miesięcy wcześniej w Poznaniu, podczas przerwy w próbie zespołu i w ciemnościach [...]. Krzysztof improwizował, grając po ciemku, a Ptaszyn zapisywał nuty skomponowanej przez niego melodii w świetle na korytarzu[4].

Roman Polański natomiast w swojej autobiografii w taki oto sposób przedstawia genezę powstania swego pierwszego ważnego filmu:

Chociaż fascynował mnie surrealizm, chciałem, żeby film zawierał pewne przesłanie. Krótkometrażówka, którą pragnąłem nakręcić, miała więc być poetycka, alegoryczna i zarazem zrozumiała. Do tych wniosków doszedłem intuicyjnie, nie wynikały wcale z przemyśleń. Pierwsze obrazy, jakie zarysowały się w mojej wyobraźni, były równie irracjonalne: dwaj mężczyźni wyłaniają się z morza, taszcząc fortepian[5].

Mając jednak świadomość skojarzeń, jakie może wywołać instrument, reżyser zdecydował się później zamienić fortepian na staroświecką szafę, co nadało opowiadanej historii wymiar bardziej uniwersalny. Fortepian jest atrybutem muzyków, szafa - każdego z nas.

„Ciekawe, że bez problemu się porozumiewali - powściągliwy indywidualista Krzyś i Romek - nerwowy, ekstrawertyczny egocentryk"[6] - pisała o Komedzie i Polańskim Emilia Batura. Jedno jest pewne, obaj artyści w swojej twórczości kierowali się zasadą „od szczegółu do ogółu”. Komeda potrafił na bazie dosłownie trzech dźwięków stworzyć niezwykle świeży i dojrzały muzycznie utwór, Polański widząc jeden absurdalny obraz, był w stanie „przerobić” go na filmowe dzieło sztuki. Metodę, jaką obaj artyści powzięli, nazwać można jednym, choć niezwykle wieloznacznym słowem - improwizacja. O tym, że ów termin odnosi się w przypadku Dwóch ludzi z szafą tak do jego warstwy wizualnej, jak i muzycznej, pisał w Sztuce krótkiego metrażu Marek Hendrykowski:

[...] Dwaj ludzie z szafą Romana Polańskiego korzystają z konwencji etiudy w sposób najpełniejszy z możliwych, to znaczy angażując w maksymalnym stopniu grę wyobraźni, poetycką wizję świata i umożliwiający jej wykreowanie element improwizacji. Dotyczy to w tym samym stopniu stylu gry aktorskiej, w którym znalazło się miejsce na błazenadę i happening [...], co sposobu opowiadania obywającego się bez jakichkolwiek schematycznych fabularnych uzasadnień i swobodnie przechodzącego od jednego epizodu do drugiego. [...] W szczególnym jednak stopniu element improwizacji znalazł swój urzekający wyraz w muzyce skomponowanej przez Krzysztofa Komedę. Po mistrzowsku oddaje ona zarówno wakacyjną beztroskę poranka nad brzegiem morza na początku filmu, jak i pełną goryczy nostalgię za lepszym światem w finale[7].

[4] M. Hendrykowski, op. cit., s. 128.

[5] R. Polański, Roman, przeł. K. i P. Szymanowscy, Warszawa 1989, s. 114-115.
[6] E. Batura, Komeda. Księżycowy chłopiec. O Krzysztofie Komedzie-Trzcińskim, Warszawa 2001, s. 89. [7] M. Hendrykowski, Sztuka krótkiego metrażu, Poznań 1998, s. 25-26. 
Motyw przewodni wykonywany na saksofonie sopranowym (w miarę rozwoju następujących po sobie wydarzeń tę samą melodię poczyna intonować wibrafon) jest niczym innym jak muzycznym analogonem szafy zrośniętej z dwoma mężczyznami. Cały film to ciągła improwizacja na jeden temat. Muzyka ulega nieustannym przekształceniom (rytm, tempo, instrumentacja, tonacja) po to jednak, by na końcu powrócić do tematu głównego. Podobnie dzieje się w warstwie wizualnej - dwaj ludzie wyłaniają się z morskich fal, odbywają swoistą wędrówkę wypełnioną scenami, które są czymś w rodzaju wariacji na temat pary bohaterów. Rzeczywistość wydaje się być równie absurdalna jak wynurzająca się z morza tytułowa szafa, która w ostatniej scenie filmu znika, tak jak się pojawiła. Dwaj ludzie z szafą są pierwszym filmem w dorobku Polańskiego, w którym kompozycja klamrowa przejawia się tak w obrazie, jak i w warstwie muzycznej. W późniejszym etapie swej twórczości reżyser rzadko będzie czynił odstępstwo od tej reguły. Udział Krzysztofa Komedy w kształtowaniu się reżyserskiego stylu Romana Polańskiego może być zatem postrzegany jako niezwykle znaczący.

Ale improwizowana kołysanka to tylko jedna strona medalu. „Do tego motywu Krzysztof skomponował kontrastowy drugi temat perkusyjno-basowy, riffowy, agresywny - metaforyczne opisanie wrogo nastawionego, brutalnego otoczenia"[8]. Ilustracyjna funkcja muzyki w Dwóch ludziach z szafą znajduje najpełniejszy wyraz właśnie w sferze emocjonalnej. Tyczy się to zarówno stanu wewnętrznego pary głównych bohaterów (zmiany tonacji z dur na moll i odwrotnie), jak i efektu, który muzyka ma wywołać w widzu.

Pierwszy przypadek znakomicie ilustruje scena $\mathrm{z}$ dziewczyną, którą „nosiciele szafy” spotykają podczas wędrówki po mieście. Podczas gdy z punktu widzenia głównych bohaterów obserwujemy młodą kobietę, przewodni motyw muzyczny słyszymy w tonacji durowej, jednak tylko po to, by w momencie odtrącenia „intruzów” tonacja zmieniła tryb na moll. Motyw muzyczny wykonywany przez Ptaszyna rozbrzmiewa teraz w postaci melancholijnej, tęsknej melodii.

Obraz poprzedzający scenę napadu, kiedy główni bohaterowie dźwigają swoje brzemię w scenerii pustego letniego amfiteatru, co tylko potęguje odczucie alienacji, Komeda zilustrował groźnymi basowymi dźwiękami imitującymi tętno człowieka znajdującego się w stanie zagrożenia. Niepokojące dźwięki kontrabasu, do którego konsekwentnie poczynają dołączać kolejne instrumenty, nie milkną $\mathrm{w}$ kolejnych scenach. Obserwujemy intensyfikujące się wraz z muzyką sceny przemocy, poczynając od „kamienowanego” przez chuliganów kotka, a na dotkliwie pobitym mężczyźnie kończąc. Przy całej swej poetyckości Dwaj ludzie z szafa momentami - jak się okazuje - są dość prozaiczni. By zrozumieć metafizykę - można by rzec musimy wyjść od fizyki.

[8] E. Batura, op. cit., s. 152-153. 
Podstawą tej poetyckiej wizji stają się w Dwóch ludziach z szafą obficie serwowane, z życia wzięte prozaizmy, by przywołać tylko bójkę z chuliganami czy próbę wejścia z szafą do zatłoczonego tramwaju. Dotyczy to również luźnych, jakby od niechcenia wprowadzanych na ekran obrazów, takich jak: umieszczona na lustrze szafy ryba płynąca wśród chmur, suita z pijakiem usiłującym wdrapać się na schody, zabójstwo nad potokiem czy tyleż prozaiczne, co całkiem surrealistyczne w swym wyglądzie składowisko beczek wypełniających przestrzeń aż po horyzont[9].

Co więcej, obrazom tym towarzyszą równie frywolnie wprowadzane i wykonywane partie instrumentalne. W tym kontekście przywołać należałoby chociażby scenę ze złodziejem wyciągającym portfel z kieszeni przypadkowo napotkanego turysty. Obrazowi temu, który jest dosłownie migawką, towarzyszy tak samo niespodziewane „wtargnięcie" szybkiego sola na saksofon tenorowy z mocno wyeksponowaną perkusją.

Warto też podkreślić, że muzyka Krzysztofa Komedy w Dwóch ludziach z szafa ma charakter zarówno dynamiczny, jak i statyczny. Okazuje się nawet, że jeden motyw muzyczny w zależności od sytuacji ekranowej oraz sposobu aranżacji pełni w tym dziele obie te funkcje, wychodząc tym samym daleko poza rolę tylko i wyłącznie lejtmotywu. Roman Polański niezwykle świadomy tego, jak ważną funkcję pełni w filmie dobrze zintegrowana $\mathrm{z}$ obrazem muzyka (o czym świadczy niesamowite muzyczne wyczucie reżysera, które objawi się w pełni w dalszych etapach jego twórczości), nie miał najmniejszych wątpliwości, kto skomponuje muzykę do jego kolejnych miniarcydzieł.

Geneza powstania muzyki do pierwszego zagranicznego filmu Romana Polańskiego przedstawia się nie mniej interesująco jak w przypadku Dwóch ludzi z szafą. Sam reżyser tak opisuje okoliczności powstania utworu.

Gruby $i$ chudy to film z tego gatunku co Dwaj ludzie z szafą. [...] Kiedy kończyłem zdjęcia, do Paryża przyjechał właśnie na koncerty zespół Komedy. To było zrządzenie losu. Krzysztof bezpłatnie napisał muzykę, a próby tej kompozycji odbywał w naszym nowym mieszkaniu. Wynajęliśmy w tym celu pianino. Koczował u nas zresztą cały zespół, a ich nocne jam sessions stały się przyczyną zatargów z dozorczynią[10].

Zanim jednak błyskotliwe kompozycje Komedy uzupełniły film, Polański umieścił w nim swoją „muzykę” (użycie cudzysłowu jak najbardziej uzasadnione). Otóż w Grubym i chudym mamy do czynienia nie tylko z w pełni zintegrowanym z obrazem dźwiękiem, ale także jego źródłem. Instrumenty muzyczne, takie jak bęben, fujarka, skrzypce czy perkusja, po prostu widzimy, mamy też nieprzyjemność słyszeć. Trudno doprawdy wskazać inny film, w którym wartość artystyczna muzyki diegetycznej - bo o niej mowa - byłaby tak nikła w porównaniu $\mathrm{z}$ rolą, jaką pełni ona w omawianej etiudzie. Funkcjonalność tej Jazz Komedy
i muzyka diege-
tyczna Polańskiego
w Grubym i chudym 
muzyki łączy się z głównym tematem filmu, którym jest motyw pana i sługi. Temat, który - dodajmy - w późniejszej twórczości reżysera znajdzie szczególne miejsce.

Wróćmy zatem do jej początków. Otóż w Grubym i chudym tytułowe role zagrali Andrzej Katelbach oraz Roman Polański. Pierwszy wcielił się w postać ospałego olbrzyma, drugi obsadził się w roli jego chuderlawego sługi (tym samym krótkometrażówka, o której mowa, stała się pierwszym w karierze filmem reżysera, w którym on sam wystąpił w roli głównej). Zadania, jakie wykonuje tytułowy Chudy, wiążą się między innymi z „,artystyczną” formą umilania czasu Grubemu. W tym celu Polański zdecydował się na dość odważny eksperyment formalny. Otóż Chudy, „uzbrojony” w różnego rodzaju instrumenty muzyczne, próbuje wygrywać na nich proste melodie tylko po to, by jego pan się nie nudził. Uzależnienie, w jakie popada bohater grany przez Polańskiego, zostało znakomicie wyrażone za pomocą ciągłego rozbudowywania kolejnych sekwencji o coraz to nowe instrumenty pojawiające się $\mathrm{w}$ kadrze. W pierwszej scenie widzimy Chudego, który oprócz gry na fujarce wybija rytm granej melodii na bębenku. W miarę rozwoju akcji uzależnienie sługi od pana staje się coraz większe, wówczas na ekranie pojawia się cała perkusja, na której główny bohater gra $\mathrm{z}$ olbrzymim zapałem, ale bez krzty artyzmu. Podobnie rzecz ma się z melodiami wygrywanymi przez Chudego na skrzypcach. Ale usługiwanie panu nie przejawia się tylko w „występach artystycznych”, w których skład wchodzą jeszcze popisy taneczne Chudego w rytm, który ustala olbrzym. Niediegetyczny jazz, który paradoksalnie pojawia się niemal wszędzie tam, gdzie w kadrze nie widzimy żadnych instrumentów, to druga strona jednak wciąż tego samego medalu.

Motyw muzyczny napisany na saksofon tenorowy znakomicie oddaje zarówno specyfikę postaci kreowanej przez Katelbacha, jak i przyziemność oraz rutynę czynności wykonywanych przez Chudego. Utwór ten, przypominający nieco słynny Take Five grupy Dave Brubeck Quartet, poprzez swoje wolne tempo, intonację oraz zastosowanie specyficznego jazzowego rodzaju metrum odgrywa w filmie bardzo ważną rolę jako muzyka ilustracyjna. Melodia towarzyszy bowiem wszystkim scenom, w których Chudy obsługuje Grubego. Są to między innymi takie czynności, jak przygotowywanie dlań obiadu, czyszczenie butów, golenie czy obcinanie paznokci. Do tej melodii Krzysztof Komeda skomponował drugi motyw, pełniący funkcję swoistego kontrapunktu. W tym celu kompozytor wykorzystał niosące dźwięki fortepianu oraz szkliste, pełne i zarazem delikatne brzmienie wibrafonu. Oba instrumenty posłużyły Komedzie do zilustrowania marzeń o Paryżu, za którym tęskni poniżany sługa. Za każdym razem, kiedy Chudy wygląda z okna, przez które dostrzega na horyzoncie swe wyśnione miasto, widz słyszy spokojną i rozmytą jak obraz Paryża melodię. Ów motyw muzyczny jest jednak systematycznie przerywany poprzez wtargnięcie groźnych akordów zwiastujących pojawienie 
się w audiosferze pierwszego ospałego tematu muzycznego, zaś w kadrze - olbrzyma. Warto w tym kontekście nawiązać do sceny, która jest swoistą syntezą dźwięków i obrazów właśnie omówionych. Otóż w chwili, kiedy Chudy za pomocą parasola ochrania twarz olbrzyma przed słońcem, powraca obraz Paryża. Tym razem jednak melodię intonowaną uprzednio przez wibrafon odgrywa saksofon tenorowy. Jest to muzyczny sygnał informujący, że pan jest w pobliżu, co oznacza, iż należy porzucić marzenia i zejść na ziemię.

Ale jest jeszcze trzeci bohater tej alegorycznej opowieści. Jego postać odgrywa w filmie rolę kluczową. Mowa o kozie. Na początku Chudy dosłownie skacze z radości na widok nowego towarzysza. Tym jednak, co nie pozwala uwierzyć w pomyślny rozwój dalszych wydarzeń, jest znany temat muzyczny towarzyszący również tej scenie. Okazuje się, że koza zostanie co prawda towarzyszem Chudego, ale będzie miał on $z$ tego powodu więcej zmartwień niż radości. Zwierzę zostaje przykute do głównego bohatera, co oznacza, że odtąd wszystkim czynnościom, jakie wykonywał do tej pory sam, towarzyszyć będzie właśnie ono. Polański rozbudowuje strukturę wizualną w filmie, podobnie jak kompozytor rozbudowuje utwór muzyczny, wzbogacając go o coraz to nowe instrumenty. Widz obserwuje ciąg dosłownie tych samych, podobnie kadrowanych scen, których już wcześniej był świadkiem. Różnica polega na tym, że są one „uzupełnione kozą”. Chudy zostaje w końcu pozbawiony swego brzemienia, dopiero teraz rozumie, że usługiwanie Grubemu nie było w gruncie rzeczy aż takie złe. Od tej pory wszystkie „obowiązki” Chudy wykonuje z radością. Mało tego, aby zaimponować Grubemu, postanawia udekorować sztucznymi tulipanami łąkę, na której ten buja się w fotelu. W scenie tej powraca wibrafon, najpierw zaznaczając posadzenie każdego kwiatka pojedynczym dźwiękiem, a potem - kiedy w kadrze pojawia się cała ukwiecona łąka z Paryżem na horyzoncie - intonując znaną subtelną melodię. Ostatnia scena filmu Gruby $i$ chudy jest zatem wielkim finałem, w którym ostateczne przesłanie filmu zostaje wyrażone za pomocą niezwykle przemyślanej kombinacji dźwięków i obrazów.

W kontekście wczesnej twórczości Krzysztofa Komedy jako kompozytora muzyki filmowej sprawą wartą odnotowania jest fakt, że jak mało który polski muzyk tworzący dla kina, Komeda bardzo szybko opanował sztukę rozumienia języka filmowego. Ostatnia nakręcona w Polsce krótkometrażówka Romana Polańskiego staje się tego najlepszym przykładem. Po Sopocie i Paryżu nadszedł czas na Zakopane. Ale zimowa sceneria posłużyła reżyserowi jedynie jako tło do zobrazowania historii ujawniającej - po raz kolejny zresztą - istotę relacji, jakie panują w świecie strunowców z człowiekiem włącznie. Dwa tytułowe ssaki, grane przez Henryka Klubę i Michała Żołnierkiewicza, to duet nieco podobny do tego, który jednocześnie bawił nas i przerażał w filmie Gruby i chudy.

Dynamiczna mandolina i statyczny klarnet w Ssakach 
Główna różnica polega na tym, że w kolejnym obrazie Polańskiego pan i sługa niemal nieustannie zamieniają się rolami. Dwójka bohaterów prowadzi ze sobą swoistą grę, której stawką jest możliwość bycia wiezionym na sankach. Zarówno sceny, w których jeden ciągnie drugiego (dynamika), jak i te przedstawiające momenty zamiany (statyka), zostały znakomicie zilustrowane muzyką. Wpadająca w ucho melodia grana na mandolinie pojawia się już w czołówce filmu. Widz zastanawia się wówczas, czy przypadkiem nie obejrzy kreskówki. Faktycznie w Ssakach odnajdujemy sporo elementów charakterystycznych dla filmu animowanego. Oprócz muzyki są to nienaturalnie przyspieszone ruchy postaci, które z tą muzyką są do granic możliwości zsynchronizowane. „Przesadny synchronizm ukazanych ruchów w obrazie, częsty zwłaszcza w filmach rysunkowych, jest źródłem swoiście filmowo-muzycznego komizmu [...]"[11]. O to między innymi chodzi w Ssakach, a jeszcze bardziej niż w przypadku wspomnianej wcześniej mandoliny, omawiany problem wiąże się z zastosowaniem przez Komedę klarnetu. Za każdym razem, kiedy w filmie ma dojść do „zmiany boisk”, dźwięki tego instrumentu ilustrują niejako jej przyczynę.

W filmie Ssaki nie ma ani jednej sceny, w której „odgłosy” z kadru nie byłyby muzyką (całkowite zawłaszczenie sfery audialnej przez tę sztukę). Stąd tak ważna funkcja instrumentu muzycznego, który podkreśla nie tylko każdy ruch, jaki wykonuje jeden z głównych bohaterów (gdy na przykład się przewraca), ale imituje też płacz w momencie, kiedy komuś dzieje się krzywda. Wróćmy jednak do rozpędzonej mandoliny, która jednak zwalnia tak samo, jak zwalnia zmęczony ssak. Otóż oprócz tempa w melodii granej przez ten instrument po jakimś czasie możemy dostrzec różnice również w obrębie rytmu. Komeda poprzez zmianę metrum $\mathrm{z}$ parzystego na nieparzyste $\mathrm{w}$ bardzo ciekawy sposób ilustruje te fragmenty opowiadanej historii, $\mathrm{w}$ których mamy do czynienia $\mathrm{z}$ sytuacjami ekstremalnymi (jeden z ssaków ciągnie sanki, idąc o kulach). Ale muzyka w Ssakach to nie tylko klarnet i mandolina. W chwili kiedy para bohaterów postanawia się pogodzić, nie na długo zresztą, słyszymy pozbawioną zupełnie nuty goryczy, napisaną w radosnej tonacji G-dur melodię intonowaną przez flet, przechodzącą w Marsz zadowolonych[12]. Mandolina powraca w ostatniej scenie. Ssaki pozbawione swego jedynego środka lokomocji, który kradnie grany przez Wojciecha Frykowskiego sprzedawca kiełbasek, noszą się teraz na zmianę na plecach. Dobrze znana już widzowi melodia informuje go, że wróciliśmy do punktu wyjścia, ponieważ ludzka (zwierzęca) natura nie ulega najmniejszym zmianom. „Jestem przeciwnikiem nadużywania muzyki filmowej. Uważam, że powinna ona być tylko tam, gdzie jest naprawdę konieczna,

[11] Z. Lissa, Estetyka muzyki filmowej, Kraków 1964, s. 394 .
[12] Tytuł utworu zaczerpnięto z partytury zamieszczonej na oficjalnej stronie internetowej Komedy: www.komeda.pl [dostęp: 20.09.2011]. 
i raczej powinno być jej za mało niż za dużo"[13]. Jeśli tę wypowiedź Krzysztofa Komedy odnieść do krótkometrażówek Polańskiego, to jest ona dowodem na zasadność tezy, że filmy te nie istnieją bez muzyki. Ssaki - z pozoru najmniej jazzowy obraz reżysera Matni - to paradoksalnie najbardziej filmowy wyczyn Komedy, jeśli chodzi o etiudy. To właśnie w ostatnim (przed pełnometrażowym debiutem) krótkim filmie Polańskiego, w warstwie audialnej w sposób sfunkcjonalizowany wykorzystane zostają niemal wszystkie elementy muzyczne: melodyka, kolorystyka, dynamika, agogika (tempo), rytmika i metrum. Polański i Komeda udowadniają, że wpływ jazzu na film (Dwaj ludzie $z$ szafą) może okazać się równie znaczący jak wpływ filmu na jazz (Ssaki), który - parafrazując wypowiedź Alicji Helman właściwie przestaje nim być. Chyba dlatego, że jest już zbyt filmowy.

[13] K. Komeda, Rola muzyki w dziele filmowym, wypowiedź w ankiecie redakcyjnej, „Kwartalnik Filmowy" 1961, nr 2 (42), s. 36. 